\title{
EFFECT OF PROTEIN UNDEGRADED SUPPLEMENTATION ON PRODUCTION AND COMPOSITION OF MILK IN DAIRY COWS
}

\author{
B.P. Widyobroto, S.P.S. Budhi and A. Agus \\ Department of Animal Science Universitas Gadjah Mada. \\ Karangmalang Campus, Yogyakarta - Indonesia \\ Corresponding E-mail: budiprasetyo@ugm.ac.id
}

Received October 12, 2009; Accepted January 28, 2010

\begin{abstract}
This research was aimed to examine the effect of undegraded protein supplementation on nutrients intake, production and milk composition in dairy cows. The purpose of this research was to provide information on the undegraded protein supplementation to increase milk production and composition in dairy cows. The research was conducted for 3 months in Boyolali-Central Java. The study used 20 lactation cows ( $<3$ months of lactation), aged 3 to 3.5 years with body weight from 350 to $400 \mathrm{~kg}$. The cows were then randomly divided into 2 groups of ten based on their body weight, milk production, lactation period and age. The first group (control) and the second group (treated), both were fed diet based on NRC (1987). The second group was added undegraded protein (UDP) of $30 \mathrm{~g} / \mathrm{l}$ milk that mixed by concentrate. The observed variables were dry matter intake (DM), organic matter (OM), crude protein $(\mathrm{CP})$, neutral detergent fiber (NDF), milk production and milk composition including fat, protein and solid non fat (SNF). Data obtained were examined by t-test.

The results showed that intake of DM, OM, and the NDF of treated and control groups were not different $(9.57 ; 8.49 ; 4.98$ vs $9.44 ; 8.38 ; 5.40 \mathrm{~kg} / \mathrm{cow} / \mathrm{d}$, respectively); however, protein intake of treated group was higher $(\mathrm{P}<0.01)$ than that of the control group $(1097 \mathrm{vs} .1210 \mathrm{~g} / \mathrm{cow} / \mathrm{d})$. Milk production of cows receiving UDP supplementation tended to be higher than that in the control group $(+1: 45$ $\mathrm{kg} / \mathrm{cow} / \mathrm{d})$. Although they tended to be lower in fat (4.13 vs. $3.88 \%)$, protein $(2.45 \mathrm{vs} .2 .27 \%)$ and SNF (7.26 vs. $6.94 \%$ ), but protein and fat production were higher for cows receiving UDP supplementation (366 each; 214 vs. 330; 196g/cow/d). It can be concluded that UDP supplementation increased milk, fat production and milk protein but it tended to reduce the level of fat, protein and SNF milk.
\end{abstract}

Keywords: fat, protein and solid non-fat milk, undegraded protein.

\section{INTRODUCTION}

The protein quality of feed for ruminant livestock varies depending on the type of plants, plant organ, and chemical or physical treatment. Protein protection (by pass) by heating or formaldehyde addition increased the undegraded protein fraction of $50-80 \%$ and did not decrease its digestibility in the intestinum (Widyobroto et al., 1995a, 1995b, 1996). Undegraded protein supplement based on the requirement of rumen microbes on nitrogen precursor have to be calculated to improve nutrient efficiency, increase production and milk quality (Widyobroto, 1992). Increasing the level of undegraded protein in the ration tended to increase the use of nutrients by host animal, although it also depend on the energy intake (Widyobroto et al., 1999, 2001).

Feed protein that was not degraded in the rumen (undegraded protein, UDP) was required by ruminants particularly for those with high production. The optimum feed evaluation system for ruminants always considers the needs of rumen microbes and the needs of host, so the rumen degradable protein (RDP) and UDP should be considered in formulating ration. NRC (1985) reported that ruminants need UDP at $39.5 \%$ of CP and $60.5 \%$ RDP of CP. Robinson et al. (1990) reported that plasma glucose concentrations rised with the increasing in the level of UDP in the rations. This was due to the high supply of glucogenic amino acids UDP in feed which can be used as a glucose precursor material in the small intestine. Sletmoen-Olson et al. (2000) reported that cows with low UDP intake, their plasma glucose concentrations were consistently higher than those consuming moderate to high UDP (53, $223,412 \mathrm{~g}$ intrinsically unstructural protein 
Table 1. Chemical Composition and Nutritive Value of Ration

\begin{tabular}{lccccc}
\hline \multirow{2}{*}{\multicolumn{1}{c}{ Ration Materials }} & \multicolumn{3}{c}{ \% DM } & Mcal/kg DM) \\
\cline { 2 - 5 } & DM & CP & NDF & UDP & NEL 1$)$ \\
\hline Corn stover & 30,00 & 9,58 & 65,66 & 44,00, & 1,62 \\
Soy bean meal-HCHO & 86,00 & 48,00 & 14,60 & 73,40 & 1,79 \\
Coffee husk & 87,00 & 11,2 & 80,2 & - & 1,02 \\
Rice bran & 86,00 & 7,60 & 61,80 & - & 0,42 \\
Cassava & 80,00 & 3,30 & 11,30 & 11,58 & 1,60 \\
Molasses & 77,0 & 5,40 & - & - & 1,19 \\
Urea & - & 287,5 & - & - & - \\
\hline
\end{tabular}

1). Calculated based on NRC (1987)

(IUP) $/ \mathrm{kg}$ ) in the first month of pregnancy during lactation period. The ration that lease excess degraded protein in the rumen will have high endogenous urea concentration in blood, milk and urine. This high concentration of urea will lead to fertility problem, decline of energy availability, environmental pollution and economic losses (Roseler et al., 1993).

Santos et al. (1998) showed that milk protein production efficiency was influenced by the ratio of protein and energy availability for milk production. Besides, it was also influenced by the level of milk production and stage of lactation. Clark (1975) reported that absorbed amino acids would be used as a precursor for the formation of milk proteins and as precursor for the formation of glucose from glucogenic. Misciattelli et al. (1999) reported that protein intake decreased through infusion of UDP in intestine significantly declines about $4 \%$ of milk production, milk protein, milk urea, $\mathrm{N}$ excretion via urine and blood, beta-hydroxy butyrate, and free fatty acids. Increasing the level of UDP in the ration had a positive effect on milk production (Chiou et al., 1995) and milk protein production (Chiuo et al., 1995; Winsryg et al., 1991). Meanwhile Castillo et al. (2001) reported that the excessive intake of UDP did not affect the production and milk quality.

The purpose of this research was to examine the influence of UDP supplementation on production and milk composition in dairy cows.

\section{MATERIALS AND METHODS}

This research used 20 dairy cows with a lactation period less than 3 months and body weight $\pm 400 \mathrm{~kg}$. Animals were grouped randomly into two based on body weight, milk production, lactation period, and age of cattle, each group consisted of 10 cows. The first group (control) and the second group (treated) were fed standard ration based on NRC (1987). In the treated group, the feed was added by the protected protein for 30 $\mathrm{g} / \mathrm{l}$ production of milk and mixed by the concentrate. Corn stover and concentrate were distributed two times a day at 8:00 and 15.00 with the proportion of 70: 30 . Corn stover was chopped and was given 2 hours after concentrate distribution.

During collection period, the corn stover was taken as a sample every 3 days, while the concentrate sample was taken at every mixing new concentrates, and at the end of the study, they were composited for analysis of DM, OM, N (AOAC, 1975), NDF, ADF (Goering and Van Soest, 1970). The remaining daily feed was weighed and sampled as much as $200 \mathrm{~g}$ and composited per cow per period for analysis of DM, OM, N, NDF, ADF.

The research was conducted for 3 months, i.e. 2 weeks of adaptation period and 2,5 months of collection period. The milk production was recorded daily, samples were taken $5 \%$ both in the morning and afternoon every three days and at the end of the last 2 weeks, it was composed of each cow to analyse protein and fat content. At the beginning and end of the study, the cow was weighed in the morning before feeding. The results of nutrient intake, production and milk quality was tested by $\mathrm{t}$ - test (SAS, 1987).

\section{RESULTS AND DISCUSSION}

\section{Intake of forages and Concentrates.}

The average intake of dairy cows during the experiment was presented in Table 2. The results showed that intake of DM, OM and the NDF of 
cattle given UDP supplementation and those of control were not different, which were 9.57; 8.49; 4.98 vs. $9.44 ; 8.38 ; 5.40 \mathrm{~kg} / \mathrm{head} / \mathrm{d}$ respectively, but protein intake was found higher $(\mathrm{P}<0.01)$ in of the ration used, excess energy in ration, and also caused decrease ration efficiency used and tended to be accumulated in the body fat (Miller, 1997).

Table 2. Nutrient Intake of Dairy Cows Receiving Control and Undegraded Protein Supplement

\begin{tabular}{lrc}
\hline \multicolumn{1}{c}{ Nutrient } & Ration \\
\cline { 2 - 3 } Forages: & Control & UDP \\
DM (Kg/head/d) & 3.91 & 3.73 \\
OM (Kg/head/d) & 3.67 & 3.50 \\
CP (g/head/d) & 375.00 & 357.00 \\
NDF (Kg/head/d) & 2.57 & 2.45 \\
NEl (Kg/head/d) & 6.33 & 6.04 \\
Concentrate: & & \\
DM (Kg/head/d) & 5.53 & 5.84 \\
OM (Kg/head/d) & 4.72 & 5.00 \\
CP (g/head/d) & 722.00 & 853.00 \\
NDF (Kg/head/d) & 2.47 & 2.53 \\
NEl (Kg/head/day) & 5.33 & 5.38 \\
Total Intake: & & \\
DM (Kg/head/day) & 9.44 & 9.57 \\
OM (Kg/head/day) & 8.38 & 8.49 \\
CP (g/head/day) & $1,097.00$ & $1,210.00^{* *}$ \\
NDF (Kg/head/day) & 5.40 & 4.98 \\
NEl (Kg/head/day) & 11.66 & 11.43 \\
Forage percentage (\%) & $38.98^{* *}$ \\
** Highly significant (P<0.01) & 41.42 & \\
& & \\
Hoy & & \\
\hline
\end{tabular}

the treated ration than those in control (1097 vs $1210 \mathrm{~g} / \mathrm{head} / \mathrm{d}$ ). This was similar to the study of Widyobroto et al. $(1999,2001)$ which found that the increase of UDP in the ration was not influenced by the intake of DM. The high protein intake in the control ration was caused by UDP supplemented of protected soybean meal which had high protein content ( $48 \% \mathrm{CP}$ ).

Eventhough intake of forages was low (38.91-42.45\% of the total ration), but fiber/structural carbohydrates content in concentrate was high (coffee husks and rice bran), hence the need/requirement of fiber still can be fullfilled. This mean that the intake of forages was low, the negative effect in the digestive process was not happen since the concentrates given still have high structural carbohydrates.

This condition could be used as a reference by farmers, especially in the dry season where the forages were difficult to get and relatively expensive. The energy could affect the efficiency
There were not just low energy and high protein content in the ration caused low protein efficiency but the ratio of energy:protein should be considered to get better protein efficiency. Thus, the condition should be consider for protein protection to avoid rumen degradation. Protein and energy intake from control and treated rations were more than enough to fulfill the need of maintenance and production. The excess of protein and energy were $342 \mathrm{vs.} 384 \mathrm{~g} / \mathrm{head} / \mathrm{d}$ and 2.11 and $2.76 \mathrm{~kg} \mathrm{NEl} / \mathrm{head} / \mathrm{d}$ respectively for control and treatment. This was similar to the results of research by Arroquy et al. (2004), that the flow rate of feed in the digestive system would be increased by supplementing rumen degradable protein (RDP). RDP supplementation has a positive effect on intake and forage digestibility, adequate availability of RDP may avoid the negative effects of non-fiber carbohidrat (NFC) supplementation against fiber digestibility. In contrast, Encinias et al. (2005) reported that 
there was no difference in intake of DM on dairy cows fed Brome grass hay (9.6\% CP) which is supplemented by undegraded protein.

\section{Milk Production and Composition.}

The average production of milk, fat and protein for cows fed control and treated rations were presented in Table 3. The results showed that milk production of cattle that received UDP supplementation tend to be higher $(\mathrm{P}<0.05)$ than that of the control $(+1.45 \mathrm{~kg} / \mathrm{head} /$ day $)$. Although there were decreasing in fat (4.13 vs. $3.88 \%)$, protein (2.45 vs. $2.27 \%)$ and SNF (7.26 vs. $6.94 \%$ ) of milk; but, protein and fat production increased $(\mathrm{P}<0.01)$ in cattle which received supplementation of UDP (366; 214 vs. 330; 196 $\mathrm{g} /$ head /day). UDP supplementation would increase the amount of protein in the small intestine. The increased of protein supply to the intestine was expected to meet the protein needs for milk production, so that milk production will increase. This was similar to the work of Petit and Tremblay (1995), that the strategy to increase the tendency of the decline of fat and protein milk, although the fat production, protein and SNF of milk increased. The decrease of fat and protein milk was due to the low fiber in the ration with supplementation UDP, hence decreased of $\mathrm{pH}$ and low production of ammonia in the rumen. This was similar to the results of research by Hristov et al. (2004a, 2004b) who stated that the energy source of feed material easily fermented in the rumen can decrease rumen ammonia concentration by reducing the production of ammonia, or by taking increased ammonia for microbial protein synthesis. The energy easily fermented in the rumen will lower the continuous ammonia production but as a whole the efficiency of ammonia used for milk protein synthesis will only increase with the increasing of ammonia intake by rumen microbia.

The average milk production was higher in cattle getting UDP supplementation as a result of their low daily production variation (Table 3 and Table 4).

Table 4 showed that daily milk production of

Table 3. Production and Composition of Milk Dairy Cows Receiving Control and Undegraded Protein Supplementation

\begin{tabular}{lcc}
\hline \multicolumn{1}{c}{ Parameter } & \multicolumn{2}{c}{ Ration } \\
\cline { 2 - 3 } Milk production (kg/head/day) & Control & + UDP \\
Milk fat (\%) & 7.99 & 9.44 \\
Milk fat production (g/head/day) & 4.13 & 3.88 \\
Milk protein (\%) & 330 & $366^{* *}$ \\
Milk protein production (g/head/day) & 2.45 & 2.27 \\
Solid Non Fat (\%) & 196 & $214^{* *}$ \\
Solid Non Fat production (g/head/day) & 7.26 & 6.94 \\
**) Highly significant $(\mathrm{P}<0.01)$ & 580 & $613^{* *}$
\end{tabular}

number of proteins which can reach in the small intestine is to increase microbial protein synthesis or undegraded protein supplementation. Supplementation undegraded protein (UDP) in dairy cattle feed was intended to increase the amount of protein in the small intestine. The increasing of UDP intake will increase the total amount of protein in the small intestine (Widyobroto, 1992).

Broderick et al. (2006) reported that rations that the protein content was decreased but still supplemented by undegraded protein did not decrease milk production. The increase of milk production in this research was in line with the cows that received supplementation UDP relatively increased and consistent compared to the control ration. The above phenomena was quite interesting to scrutiny further during the period of lactation, so that the persistence of milk production during lactation period can be evaluated.

Although the response of cattle supplemented by UDP on milk production and milk constituent was quite good compared with control, even though it was still under optimum compared with results in developed countries, it could be happened: 1) Body condition of experiment livestock (dry season) was relatively 
Table 4. Milk Production Dairy Cows Receiving Control and Undegraded Protein Supplementation (12 Weeks of Period Collection)

\begin{tabular}{ccc}
\hline \multirow{2}{*}{ Week } & \multicolumn{2}{c}{ Ration } \\
\cline { 2 - 3 } & Control & + UDP \\
\hline 1 & 7.53 & 7.9 \\
2 & 8.42 & 8.65 \\
3 & 7.58 & 8.62 \\
4 & 7.98 & 9.22 \\
5 & 7.24 & 8.83 \\
6 & 8.35 & 9.19 \\
7 & 8.36 & 9.32 \\
8 & 8.53 & 9.18 \\
9 & 7.68 & 9.28 \\
10 & 8.1 & 9.81 \\
11 & 8.25 & 9.57 \\
12 & 8.78 & 10.06 \\
\hline
\end{tabular}

poor, hence the improved ration was used to improve body condition. This was supported by the high weight gained per cow/day during the research on UDP supplemented rations than those of controls (0.102 vs. $0.340 \mathrm{~kg} /$ cow/day). 2) Cow's milk production used was relatively low $( \pm$ $9 \mathrm{~kg} / \mathrm{head} /$ day). Santos et al. (1998) reported that low production of dairy cows (4500 kg / lactation) was able to meet protein needs on microbial protein synthesis; in contrast, the high production of dairy cows (9000-14000 kg/lactation) requires a sufficient source of undegraded protein to be used directly in the intestinum. The results of this research was similar to the one reported by Hristov et al. (2004), that dry matter intake, milk production, fat and milk protein was not statistically different between rations containing high RDP (HRDP) and those with sufficient RDP (ARDP). Furthermore, Dunlap et al. (2000) stated that there was tendency of increasing $\mathrm{N}$ excretion in urine, blood plasma and milk urea $\mathrm{N}$ concentration was higher in rations with high content of RDP compared to the rations with sufficient of RDP.

The efficiency of $\mathrm{N}$ in milk decreased in the HRDP rations. Furthermore, RDP in the rations of lactation cow was not efficiently used for microbial protein synthesis and most excreted with the secretion of $\mathrm{N}$ urine. The increase of $\mathrm{CP}$ or RDP concentration in the ration would decrease efficiency of $\mathrm{N}$ conversion in the ration to milk protein and less efficient used of rumen ammonia $\mathrm{N}$ for milk protein synthesis.

\section{CONCLUSION}

Based on the results, it can be concluded that undegraded protein supplementation tends to increase milk production and has good persistence. Fat and milk protein production increased with undegraded protein supplementation.

\section{ACKNOWLEDGMENT}

The author would like to thank to Ir Yoyok Sunaryo (CV. Argasari Farm, Boyolali) who has supported the success of this research.

\section{REFERENCES}

Arroquy, J.I, R.C. Cochran, M. Villarreal, T.A. Wickersham, D.A. Llewellyn, E.C. Titgemeyer, T.G. Nagaraja, D.E. Johnson, and D. Gnad. 2004. Effect of level of rumen degradable protein and type of supplemental non-fiber carbohydrate on intake and digestion of low-quality grass hay by beef cattle. Anim. Feed Sci. Technol. $115: 83-99$.

AFRC. Agriculture and Food Research Council. 1992. Nutritive requirements of ruminant animals: protein (Report 9). Nutrition Abstracts and Reviews, v.62, p.787-835.

AOAC. 1975. Official Methods of Analysis Association $\left(13^{\text {th }}\right.$ Ed.), Official Analytical Chemist. Association of Official Analytical Chemist, Washington, DC.

Broderick, G.A., M.J. Stevenson and R.A. Patton. 2006. Effect of dietary crude protein, rumen-undegraded protein and rumenprotected methionine on milk production of lactating dairy cows [abstract]. Journal of Dairy Science. 89(suppl. 1):402.

Castillo.A.R., E. Kebreab, D. E. Beever, J. H. Barbi, J. D. Sutton, H. C. Kirby, and J. France. 2001. The effect of energy supplementation on nitrogen utilization in lactating dairy cows fed grass silage diets. $\mathbf{J}$ Anim. Sci. 79: 240-246.

Chiou-Shyang-Peter Wen, Kuen-Jaw Chen, Kwen-Sheng Kuo, Jenn-Chung Hsu, and Bi Yu. 1995. Studies on the application of an undegradable system to high yielding dairy cattle in Taiwan. Anim. Feed Sci. Technol. 54:93-102.

Clark J.H. 1975. Lactational responses to post 
ruminal administration of proteins and amino acids. J. Dairy Sci. 58:1178.

Dunlap, T.F., R.A. Kohn, L.W. Douglass and R.A. Erdman. 2000. Diets deficient in rumen undegraded protein did not depress milk production. J. Dairy sci. 83: 1806-1812.

Encinias, A. M., G. P. Lardy, J. L. Leupp, H. B. Encinias, L. P. Reynolds, and J. S. Caton. 2005. Efficacy of using a combination of rendered protein products as an undegradable intake protein supplement for lactating, winter-calving, beef cows fed brome-grass hay. J. Anim. Sci. 83:187-195

Goering, H.K., Van Soest, P.J., 1970. Forage fiber analysis (apparatus, reagents, procedures and some applications). In: Agriculture Handbook No. 379. Agriculture Research Service, United States Department of Agriculture, Washington, USA.

Hristov, A.N., R. P. Etter, J. K. Ropp, and K. L. Grandeen. 2004. Effect of dietary crude protein level and degradability on ruminal fermentation and nitrogen utilization in lactating dairy cows. J. Anim Sci. 82 : 3219 $-3229$

Hristov, A.N., J. K. Ropp, K. L. Grandeen, S. Abedi, R. P. Etter, A. Melgar, and A. E. Foley. 2004. Effect of carbohydrate source on ammonia utilization in lactating dairy cows. J. Anim Sci. 83 : 408 - 421)

NRC. 1987. Nutrient Requirements of Dairy Cattle. Sixth revised ed. National Academic Science. Washington, D.C.

Petit H.V. and G.F. Tremblay. 1995. Ruminal fermentation and digestion in lactating cows fed grass silage with protein energy supplements.. J. Dairy Sci. 78:342-357

Robinson, P.H., R.E. Mcqueen and P.L. Burgess. 1990. Influence of rumen undegraded protein levels on feed intake and milk production of dairy cows. J. Dairy Sci. 74: $1623-1631$

Roseler, D. K., J. D. Ferguson, C. J. Sniffen and J. Herrema. 1993. Dietary protein degradability effects on plasma and milk urea nitrogen and milk nonprotein nitrogen in Holstein cows. J. Dairy Sci. 76:525-534.

Santos, F.A.P., J.E.P. Santos, C.B. Theurer, and J.T. Huber. 1998. Effect of rumen undegradable protein on dairy performance. A 12-year literatur review. J. Dairy Sci. 81:3182-3213.

SAS Institut Inc. 1987. SAS/STAT Guide for personal Computers, Version 6 Editions.
SAS Institut Inc. Cary, NC, 1028 p.

Sletmoen-Olson, K.E., J.S. Caton, K.C. Olson, D.A. Redmer, J.D. Kirsch and L.P. Reynolds. 2000. Undegraded intake protein supplementation: II. Effect on plasma hormone and metabolite concentration in periparturient beef cows fed low quality hay during gestation and lactation. J. Anim. Sci. 78: 456-463.

Widyobroto BP., SPS. Budhi, and A. Agus. 2002. Effect of Rumen Undegraded Protein Level on Nutrient Digestibility and Rumen Fermentation Parameters of Dairy Cow. Buletin Peternakan UGM. Edisi November 2002. Hal. 57-63.

Widyobroto BP., SPS. Budhi, and A. Agus. 2001. Effect of undegraded levels on rumen fermentation parameters kinetic and microbial protein synthesis in Friesian Holstein Grade Cows. J. Indonesian Trop. Anim.Agric.. Faculty of Animal Science. Diponegoro University, Special Edition 211-221. ISSN : 0410-6320.

Widyobroto BP., SPS. Budhi and A. Agus. 2001. Effect of undegraded protein level on passage rate of particles in the digestive tract of dairy cows. Proceeding Asosiasi Ilmu Nutrisi dan Makanan Ternak Indonesia. Hal. 21-22.

Widyobroto BP., M. Soejono, H. Hartadi, D.A. Kusumaningrum. 2001. Pengaruh tingkat undegraded protein terhadap produksi dan kualitas susu sapi perah. Buletin Peternakan UGM. Edisi Tambahan. Desember 2001. Hal. 74-80.

Widyobroto BP., R. Utomo, Kustantinah dan S. Windiharti. 2000. Effect of heating soybean meal on rumen degradability of protein and intestinal digestibility of undegraded protein in dairy cows. Buletin Peternakan UGM. Edisi Tambahan Desember 2000. Hal. 64-69.

Widyobroto B.P., SPS. Budhi, A. Agus and B. Santosa. 1999. Effect of undegraded protein level on nutrient digestibility and microbial protein synthesis of dairy cows. In : Lobley GE, A. White and JC. MacRae. (Ed). Protein metabolism and nutrition. Book of abstracts of the VIIIth International Symposium on Protein and Metabolism. P. 72. EAAP publication Wageningen Holland.

Widyobroto B.P. 1999. Pengaruh Tipe Karbohidrat dan Aras Undegraded Protein 
terhadap Konsumsi, Kecernaan Nutrien dan Parameter Fermentasi Rumen Sapi Peranakan Friesian Holstein, Buletin Sintesis Nomor : 11 Tahun VII, Agustus 1999, Hal. 1-8.

Widyobroto B.P., C.T. Noviandi, A. Agus, H. Hartadi. 1998. Effect of concentrate type on dietary nitrogen partition in lactating friesian holstein crossbreed cows. Buletin of Animal Science Supplement Edition, Hal. 179-188.

Widyobroto BP., S. Padmowijoto, R. Utomo and M. Soejono. 1995 In Sacco degradation of eight tropical forages. Ann. Zootch. 44(Suppl), 194.

Widyobroto, B. P. 1992. Influence de la proportion et de la nature du concentre sur les sites et la dynamique de la digestion chez la vache haute productrice. These Docteur de l'Universite de Rennes I.

Winsryg, M.D., M.J. Arambel, and J.L. Walters. 1991. The effect of protein degradability on milk composition and production of early lactation, somatotropin-injected cows. J. Dairy Sci. 74: 1648-1653. 